\title{
METODE
}

\section{KARTIRANJE MORSKIH TRAVNIKOV S PODATKI MNOGOSNOPNEGA SONARJA}

\author{
AVTORJI
}

\section{Sašo Moškon}

Harpha sea, d.o.o. Koper, Čevljarska ulica 8, SI - 6000 Koper, Slovenija; sasom@harphasea.si

\section{dr. Janez Žibert}

Univerza na Primorskem, Fakulteta za matematiko, naravoslovje in informacijske tehnologije, Glagoljaška 8, SI-6000 Koper, Slovenija; janez.zibert@upr.si

\section{dr. Branko Kavšek}

Univerza na Primorskem, Fakulteta za matematiko, naravoslovje in informacijske tehnologije, Glagoljaška 8, SI-6000 Koper; branko.kavsek@upr.si

DOI: $10.3986 / G V 87106$

UDK: 551.462:681.883

COBISS: 1.01

\section{IZVLEČEK}

\section{Kartiranje morskih travnikov s podatki mnogosnopnega sonarja}

Prispevek obravnava metodologijo zbiranja akustičnih podatkov o morskem dnu in njihovo uporabo za kartiranje morskih travnikov. Metoda omogoča hitro in učinkovito kartiranje velikih območij morskih travnikov in zagotavlja zvezno pokritost na celotnem obravnavanem območju. V prispevku predstavimo različne akustične sisteme ter njihove prednosti in slabosti pri uporabi za kartiranje morskega dna. Opisan je postopek zajema akustični podatkov, postopek obdelave akustični podatkov, izračun značilk iz akustičnih podatkov ter metode strojnega učenja, ki so uporabljene za kartiranje. Razvita metodologija je preizkušena na realnih podatkih o morskem dnu, posnetih v slovenskem morju, na območju med Izolo in Koprom.

\section{KLJUČNE BESEDE}

hidrogeografija, mnogosnopni sonar, kartiranje morskega dna, morski travniki

\begin{abstract}
Mapping of marine meadows using multibeam sonar data

This paper deals with the methodology of collecting acoustic data of the seabed and its use for mapping of marine meadows. The method enables fast and efficient mapping of large areas of marine meadows and provides continuous coverage throughout the region. In this paper we present various acoustic systems and their advantages and disadvantages for the mapping of the seabed. Furthermore we present acoustic data acquisition, acoustic data processing, calculation of the acoustic data features and machine learning methods used for mapping. The developed methodology was tested on real acoustic data, recorded in the Slovenian sea, in the area between Izola and Koper.
\end{abstract}

\section{KEY WORDS}

hydrogeography, multibeam sonar, mapping of the seabed, marine meadows

Uredništvo je prispevek prejelo 9. decembra 2014. 


\section{Uvod}

V prispevku predstavljamo postopek kartiranja morskih travnikov na podlagi akustičnih podatkov mnogosnopnega sonarja. Morski travniki so zelo pomembni habitati za življenje nevretenčarjev, rib in mnogih ptic, poleg tega varujejo obalo pred erozijo, s produkcijo kisika ključno prispevajo k oksigenaciji morske vode in so pomemben bio-indikator stanja obalnega morja. V slovenskem morju morski travniki ne dosegajo večjih globin zaradi motnosti vode; najdemo jih do globine $8 \mathrm{~m}$ (Jogan, Kotarac in Lešnik 2004).

Meritve smo izvedli z mnogosnopnim sonarjem. Mnogosnopni sonar je aktiven senzor, ki izkorišča fizikalne lastnosti širjenja ultrazvočnih signalov v vodi za merjenje razdalje do morskega dna. Najpogosteje je nameščen na plovilu. Prednost pred preprostejšim enosnopnim sonarjem je sposobnost merjenja $\mathrm{v}$ več smereh hkrati. Enosnopi sonar uporablja en snop, širok okoli $20^{\circ}$, usmerjen navpično proti morskemu dnu. Mnogosnopni sonar uporablja usmerjene snope s katerimi meritev ne izvaja le navpično, pač pa pod različnimi koti od $-60^{\circ}$ do $+60^{\circ}$ glede na normalo plovila. Mnogosnopni sonarji so se začeli uporabljati v sedemdesetih letih prejšnjega stoletja; sprva v vojaške namene. Prvi komercialni sonar je bil izdelan leta 1977. V kombinaciji z GNSS (globalni navigacijski satelitski sistem) in INS (inercialni navigacijski sistemi) opazovanji je mogoče meritve sonarja zelo natančno umestiti v prostor. Meritve sodobnih sonarjev so dobra podlaga za izdelavo podrobnih navtičnih zemljevidov (Karničnik, Klanjšček in Radovan 2006) in digitalnih globinskih modelov (batimetrij), hkrati pa so pomemben vir informacij za arheološke, naravovarstvene, oceanografske in geološke raziskave (Fridl, Kolega in Žerjal 2008; Poglajen in Slavec 2012).

Kartiranje morskega dna lahko opravljamo vizualno, mehansko ali akustično. Vse vizualne metode (potapljači, video snemanje, fotografiranje) in mehanske metode (zajemanje vzorcev, pregledovanje) so počasne in zahtevajo veliko truda, posledično so tudi drage in neprimerne za pregledovanje velikih območij morskega dna. Alternativa so akustične metode, s katerimi lahko hitro obdelamo velika območja, saj lahko podatke zajemamo kar iz premikajočega se plovila, s pomočjo sonarjev.

V zadnjem desetletju smo bili priča velikemu napredku pri tehnologijah za kartiranje kopnega. Najprej $\mathrm{z}$ analizo letalskih in kasneje satelitskih posnetkov je sodobna tehnologija omogočila natančno kartiranje različnih habitatov, raziskave krčenja gozdov in podobno (Lefsky s sodelavci 2002; Kolega in Poklar 2012).

Oceani prekrivajo $71 \%$ površja zemlje in o njih vemo bistveno manj kot o kopnem. Podatke naj bi imeli le o $5 \%$ morskega dna, pa še ti se po kakovosti in ločljivosti ne morejo primerjati s satelitskimi podatki o kopnem (Brown 2009). Pri različnih kartiranjih kopnega se uporablja optične metode in avtomatska klasifikacija. Razvoj zračnih in satelitskih sistemov za daljinsko zaznavanje je v zadnjih nekaj desetletjih povečal dostopnost optičnih in laserskih daljinsko-zaznanih podatkov za okoljske raziskave širših območij. To je bistveno pripomoglo k boljšemu razumevanju prostorskih vzorcev na kopnem (O'Neill s sodelavci 1999; Franklin 2009).

Uporabnost optičnih metod na morju je omejena na plitva obalna območja zaradi omejene penetracije svetlobe skozi vodo. Ustreznejši so batimetrični laserski sistemi z zelenim laserjem, ki lahko v bistri vodi dosežejo do 50 metrov globine (Niemeyer in Soergel 2013), vendar so še vedno zelo odvisni od motnosti vode. Še posebej omejena je uporabnost optičnih in laserskih metod v slovenskem morju in splošno v velikem delu severnega Jadrana zaradi zelo motne vode. Največje težave so v zalivih, kjer so morski tokovi manj izraziti, vpliv valovanja večji in zamuljenost izrazita.

Za kartiranje morskih travnikov so ravno zalivi najbolj zanimiva območja, saj je v zalivih največji delež morskih travnikov. Mnogosnopni sonarji uporabljajo zvočne signale, ki so neodvisni od prosojnosti vode in nam omogočajo zbiranje kakovostnih podatkov tudi na območjih, kjer optične in laserske metode odpovejo. Poleg tega mnogosnopni (multibeam echo sounders - MBES) sistemi dosegajo bistveno višjo kakovost in ločljivost po kriterijih mednarodne hidrografske organizacije IHO (International Hydrographic Organization). Mnogosnopni sistemi ustrezajo kriterijem po IHO standardu Special Order 
meritev, sistemi z batimetričnim laserjem pa le kriterijem po IHO standardu Order 1 meritev (Guenther s sodelavci 2000; IHO 2008).

Razvili smo sistem za obdelavo velikih količin podatkov, pridobljenih z meritvami mnogosnopnega sonarja ter sistem za predobdelavo podatkov (na primer izločanje slabih meritev, kompenzacija nastavitev, normiranje podatkov). Prav tako smo preučili ustrezne statistične metode in metode strojnega učenja za iskanje ustreznih značilk, ki bi bile primerne za klasifikacijo morskega dna. Razvita sistema, izbrane metode in značilke smo združili v celovit programski paket, ki na vhodu sprejme surove podatke mnogosnopnega sonarja in nam na izhodu vrne zemljevid morskih travnikov.

Članek je sestavljen iz osem poglavij. V poglavju 2 so predstavljeni različni akustični sistemi ter njihove prednosti in slabosti pri uporabi za kartiranje morskega dna. V poglavju 3 je predstavljena uporabljena oprema in opisan postopek zajema akustični podatkov. Poglavje 4 opisuje postopek obdelave akustični podatkov: izločanje slabih meritev ter izločanje vplivov nastavitev sistema na podatke. V poglavju 5 je predstavljen nabor značilk, izračunanih iz akustičnih podatkov. Poglavje 6 predstavi uporabljene metode strojnega učenja in metodo preverjanja dobljenih rezultatov. V poglavju 7 je opisan preizkus razvite metodologije na realnih podatkih o morskem dnu, posnetih v slovenskem morju, na območju med Izolo in Koprom. $\mathrm{V}$ poglavju 8 komentiramo dobljene rezultate in predstavimo smernice nadaljnjih raziskav.

\section{Teoretična izhodišča}

V zadnjih letih se, predvsem zaradi razvoja akustičnih sistemov, raziskovalci, ki preučujejo morje, približujejo kakovosti in ločljivosti kartiranja kopnega (Brown 2009). Razvoj akustičnih raziskovalnih metod kot so enosnopni sonar (SB - single-beam echo sounder), sistem bočnega sonarja (SSS - sidescan sonar systems) in v zadnjem času mnogosnopni (MBES - multibeam echo sounder) sistemi zagotavljajo orodja za raziskave širših območji morskega dna (Mayer 2006; ICES 2007). Bistvene razlike med navedenimi akustičnimi sistemi so prikazane na sliki 1 . Ločljivost akustičnih sistemov je odvisna od lastnosti le-teh, izvedbe meritev in v nekaterih primerih tudi od globine. Načeloma je lahko od nekaj deset metrov pa vse do nekaj deset centimetrov (Anderson s sodelavci 2008). S kombinacijo novih akustičnih metod in konvencionalnih metod $\mathrm{z}$ zajemanjem vzorcev, se ponujajo nove možnosti raziskav in določanja bioloških in geoloških značilnosti morskega dna. V zadnjem desetletju smo bili priča mnogim poskusom visoko ločljivostnega kartiranja morskega dna zaradi bolj široko dostopnih in cenejših orodij, skupaj z velikim napredkom $\mathrm{v}$ računski zmogljivosti računalnikov in geografskih informacijskih sistemov (Mayer 2006).

Najpreprostejši akustični sistem, ki beleži povratni signal odbit od morskega dna, je enosnopni sonar. Podatke enosnopnega sonarja je veliko lažje obdelovati v primerjavi s podatki bočnih ali mnogosnopnih sonarjev. Enosnopni sonar zbira podatke le o morskem dnu navpično pod plovilom. Bočni in mnogosnopni sonarji pa beležijo več odbojev hkrati, levo in desno od plovila in tako zbirajo podatke o širokem pasu morskega dna. Bočni sonarji so med snemanjem s plovilom povezani s kablom in jih plovilo vleče za seboj, kot je prikazano na sliki 1. Mnogosnopni sonarji so pritrjeni neposredno na plovilo. Prednost mnogosnopnih sonarjev pred bočnimi je hkratno zbiranje podatkov o globinah in intenzitetah odboja. Pri bočnih in mnogosnopnih sonarjih je interakcija akustičnega signala z morskim dnom, predvsem na območju, ki ni navpično pod plovilom, zelo zapletena. Pomanjkljivost enosnopnega sonarja je pokrivnost oziroma natančnost izdelanih zemljevidov morskega dna. Pri kartiranju s podatki enosnopnega sonarja je treba dobljene podatke v posameznih točkah interpolirati prek celotnega območja. To pri kartiranju homogenih delov morskega dna ne povzroča težav, lahko pa vodi do precejšnjih napak na nehomogenih območjih, kjer nimamo dovolj akustičnih podatkov. Poleg tega $\mathrm{z}$ naraščanjem globine narašča velikost akustičnega odtisa (območje od katerega se odbije zvočni snop). Pri enosnopnih sonarjih je širina zvočnega snopa med $15^{\circ}$ in $25^{\circ}$, kar je relativno veliko glede na mnogosnopne sonarje, ki 
uporabljajo snope širine do $1^{\circ}$. To povzroči omejeno uporabnost enosnopnih sonarjev na večjih globinah (Brown 2007). Sodobni mnogosnopni sonarji sicer oddajajo snop širine do $120^{\circ}$, vendar ne uporabljajo enega sprejemnika, pač pa matriko 240 usmerjenih sprejemnikov. Sprejemniki so z zamikom $0,5^{\circ}$ usmerjeni vsak proti svojemu kosu morskega dna. Tako $\mathrm{z}$ enim akustičnim odbojem zabeležijo podatke o morskem dnu $60^{\circ}$ levo in $60^{\circ}$ desno od normale plovila in dosežejo ločljivost $0,5^{\circ}$. Na globini 20 metrov pod plovilom to pomeni 20 centimetrsko ločljivost. $V$ večini primerov danes bočni in mnogosnopni sonarji močno prekašajo enosnopne sonarje (Walker, Riegl in Dodge 2008; Greenstreet s sodelavci 2010).

$\mathrm{V}$ zadnjih letih so se mnogosnopni sonarji pokazali za najprimernejše orodje za raziskovanje morskega dna, predvsem zaradi možnosti, da hkrati beležijo batimetrične podatke in odboje od dna na širokem območju levo in desno od plovila. Podobno kot bočni nam tudi mnogosnopni sonarji omogočajo kontinuirano prekrivnost območja, ki ga raziskujemo, treba je le načrtovati paralelne linije snemanja na primerni oddaljenosti, da zagotovimo ustrezen preklop snemalnih pasov. Mnogosnopni sonarji zahtevajo natančne GNSS sisteme in INS sisteme za zaznavo premikov, da dobimo natančne lokacije vseh odbojev (Van Overmeeren s sodelavci 2009). Na trgu je veliko različnih sistemov, ki se razlikujejo po namenu ter globini, do katere lahko merijo. Do nedavnega je bila uporaba mnogosnopnih sonarjev vakustičnem kartiranju morskega dna omejena zaradi visokih stroškov snemanja in tehničnih omejitev pri shranjevanju ter obdelavi podatkov (Le Bas in Huvenne 2009). Z večanjem računske moči računalnikov, pocenitvijo shramb podatkov in večjo dostopnostjo mnogosnopnih sonarjev, so se le-ti začeli pogosteje uporabljati kot raziskovalna orodja in orodja za snemanje odbojev od morskega dna. Večje število snemanj z mnogosnopnimi sonarji pomeni tudi več podatkov in omogoča več raziskav na tem področju.

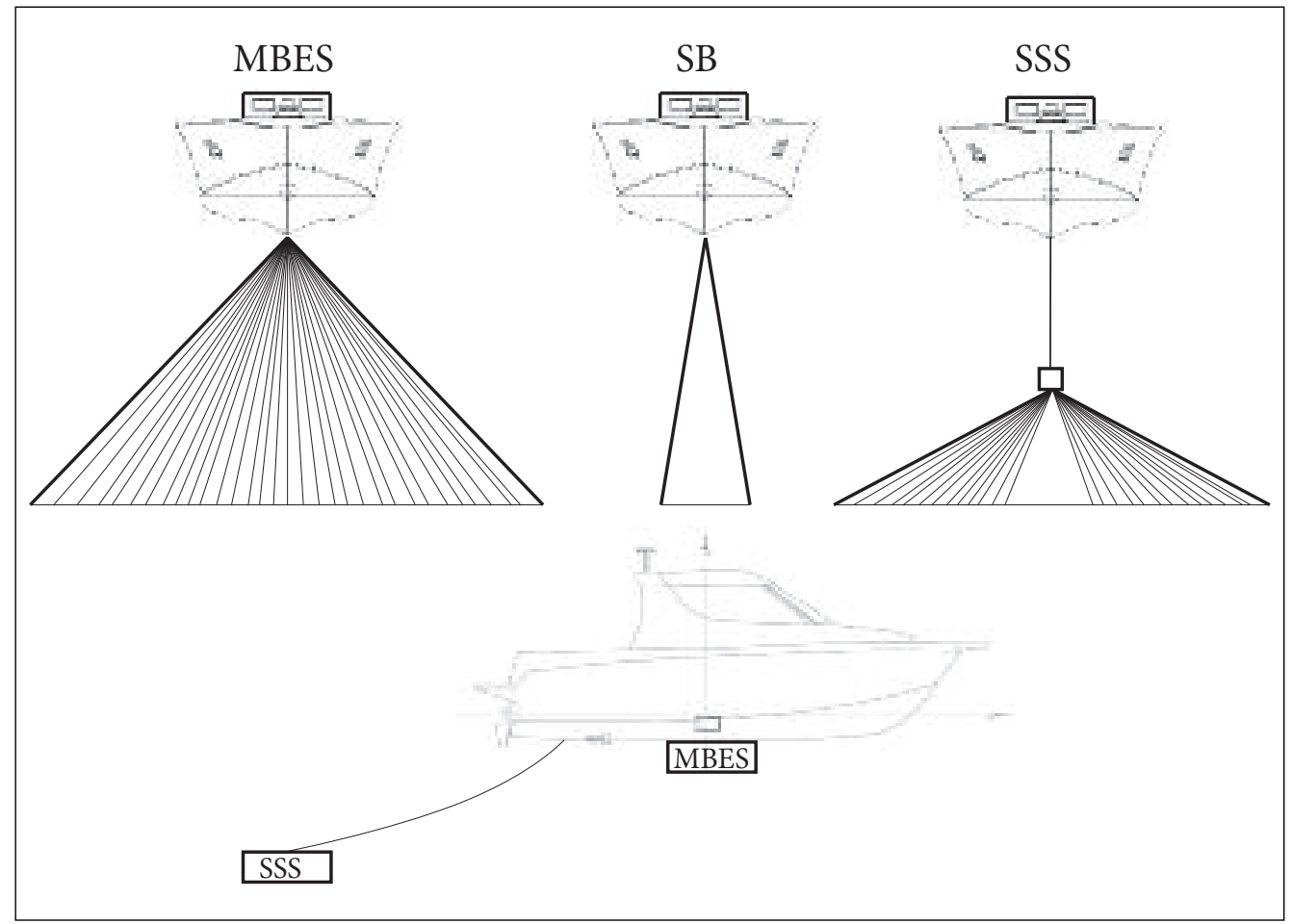

Slika 1: Prikaz različnih tipov sonarjev: mnogosnopni sonar (MBES), enosnopni sonar (SSS) in bočni sonar (SSS). Spodnji del slike prikazuje MBES sonar pritrjen na plovilo in SSS sonar, ki je pritrjen s kablom in ga plovilo vleče za seboj. 


\section{Meritve}

Kot je bilo poudarjeno, so se za najbolj primerno orodje zbiranja podatkov izkazali podatki posneti $\mathrm{z}$ mnogosnopnimi sonarji. Meritve je izvedel strokovnjak $\mathrm{z}$ mednarodno licenco iz podjetja Harpha Sea, d. o. o., kar omogoča, da so meritve priznane s strani mednarodne hidrografske organizacije IHO. Z naprednimi GNSS sistemi v kombinaciji s sodobnim mnogosnopnim sonarjem smo poskrbeli za zajem kakovostnih podatkov s centimetrsko natančnostjo. Meritve morskega dna smo izvedli s plovilom Lyra dolžine 8 metrov, na katerem je stalno vgrajen mnogosnopni sonar SeaBat 8125, podpovršinski sonar SES2000-compact ter enosnopni sonar HydroStar. Vsi sonarji so integrirani z GNSS sprejemnikom Javad Duo-G2D ter INS senzorjem TSS Mahrs.

Mnogosnopni sonar Reson SeaBat 8125 zadošča vsem kriterijem po IHO standardu Special Order meritev (IHO 2008). Z uporabo 256 dinamično usmerjenih sprejemnih snopov, SeaBat 8125 posname 120 stopinj morskega dna hkrati. Zaznava morskega dna s tem sonarjem je zelo zanesljiva; ločljivost globine je $6 \mathrm{~mm}$, meritve pa lahko v realnem času spremljamo na zaslonu sonarja. Vgrajen napredni avtopilot omogoča lažji nadzor nad linijo meritve. Stabilizacija nagiba poskrbi za uspešno zaključene meritve tudi v slabem vremenu, brez izgube natančnosti. V kombinaciji z večsnopnim sonarjem se uporablja tudi SVP (Sound Velocity Profiler). SVP je orodje za meritev hitrosti zvoka v vodnem stolpcu. Zaradi različnih temperatur vode na različnih globinah pride do loma valovanj, v našem primeru zvoka. Lomne količnike moramo upoštevati, da lahko ustrezno interpretiramo meritve in dobimo natančno izmerjene globine. Za določanje položaja plovila uporabljamo GNSS RTK metodo izmere z navezavo na mrežo SIGNAL. Inercialni senzor TSS Mahrs meri nagib, naklon, zasuk oziroma usmerjenost plovila. Natančnost izmerjene usmerjenosti (heading) je $0,1^{\circ}$, natančnost izmerjenega nagiba (roll) in naklona ( $p$ itch) je $0,03^{\circ}$. Kombinacija GNSS sprejemnika in inercialnega senzorja nam zagotavlja kakovostne podatke za natančno umeščanje v prostor - neposredno georeferenciranje.

Meritve se izvaja na vnaprej določenem območju. Za izbrano območje se pripravi načrtovane linije meritev, ki se jih nato med samo plovbo prilagaja, da se doseže ustrezen preklop snemalnih pasov. Povprečna hitrost plovila med izvajanjem meritev je 5 vozlov $(9 \mathrm{~km} / \mathrm{h})$. Sonar snema $60^{\circ}$ levo in $60^{\circ}$ desno od normale plovila, kar pri globini 20 metrov pomeni 70 metrov širok pas morskega dna. Če upoštevamo $20 \%$ prekrivanja linij za kontrolo kakovosti meritev in $10 \%$ porabe časa za obračanje plovila med linijami, sledi, da je mogoče v eni uri meritev posneti 50 hektarjev morskega dna. Pokrivnost se linearno zmanjšuje $\mathrm{z}$ manjšanjem globine. Dodatno je treba upoštevati več izgube časa pri manevriranju v plitvih obalnih območjih, vendar je hitrost zbiranja podatkov še vedno zelo velika v primerjavi $\mathrm{z}$ vizualnimi in mehaničnimi metodami kartiranja morskega dna.

\section{Obdelava podatkov}

Pri razvoju metodologije in sistema za avtomatsko predobdelavo velikih količin podatkov, pridobljenih z meritvami mnogosnopnega sonarja, smo se osredotočili predvsem na izločanje vpliva nastavitev sistema in uravnavanje odvisnosti odboja od vpadnega kota signala. Zelo pomemben dejavnik je tudi preverjanje kakovosti meritev in izločanje slabih podatkov. Običajno preverjanje kakovosti meritev in izločanje slabih podatkov izvajamo ročno s pomočjo ustreznih strokovnjakov. V postopku razvoja sistema za kartiranje morskega dna, smo razvili modul za avtomatsko čiščenje podatkov.

Med meritvami občasno prihaja do motenj, prav tako pa vsi podatki niso enako zanesljivi. Najbolj vprašljivi so podatki na robu območja meritev posamezne linije, kjer so vpadni koti akustičnih signalov največji. Sam sistem beleži podatke o kakovosti odboja in kakovosti sprejetega signala ter tudi o morebitnih težavah GNSS sprejemnika in INS-senzorja. Pri ročnem čiščenju podatkov se je izkazalo, da si lahko delo zelo olajšamo z ustreznim načrtovanjem meritev. Med načrtovanjem meritev smo upoštevali 
preklop snemalnih pasov. S preklopom si zagotovimo dvojne podatke z različnim kotom vpada na najbolj kritičnih delih, kar nam omogoči kontrolo meritev.

Za grobo izločanje slabih podatkov smo preizkusili veliko filtrov, ki uporabljajo statistične lastnosti odbojev. Za najbolj učinkovitega se je izkazal medianin filter (Brownrigg 1984). S pomočjo medianinega filtra in upoštevanjem medčetrtinskega razmika (razmik med četrtino najmanjših in četrtino največjih vrednosti) kot mere razpršenosti, smo uspešno izločili slabe meritve in ohranili le kakovostne podatke. Podatki o občutljivosti sprejemnika, moči oddanega pulza, količniku predvidene absorpcije zvoka v vodi in predvidenih izgub moči signala so pomembni, ker odražajo spremembe nastavitev, ki jih opravlja strokovnjak med meritvami. Za potrebe akustičnega kartiranja morskega dna bi bilo bolje, da bi bila večina teh nastavitev stalna in bi torej lastnosti odbojev neposredno odražale tip tal. Večina meritev z mnogosnopnimi sonarji se izvaja $\mathrm{z}$ namenom merjenja globin, kjer se nastavitve prilagajajo, da se doseže ustrezna natančnost meritev na določeni globini morja. Za potrebe akustičnega kartiranja smo takšne podatke ustrezno obdelali in izločili vpliv nastavitev sistema nanje.

Prvi korak predobdelave podatkov je izločitev vpliva nastavitve moči oddajnika in občutljivosti sprejemnika.

Uporabili smo formulo (ICES 2007):

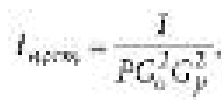

kjer je $I$ intenziteta oddanega pulza, $P$ moč oddajnika, $G_{0}$ sistemska občutljivost sprejemnika in $G_{p}$ programsko nastavljiva občutljivost sprejemnika.

Poleg prej omenjenih nastavitev so intenzitete odboja močno odvisne tudi od vpadnega kota signala, čemur pravimo kotna odvisnost. Uravnavanje kotnih odvisnosti odbojev je eden izmed glavnih izzivov akustičnega kartiranja morskega dna. V literaturi najpogosteje naletimo na dva pristopa - teoretičnega in empiričnega (ICES 2007). Teoretični pristop temelji na uravnavanju kotnih odvisnosti s pomočjo teoretičnih modelov izpeljanih iz fizikalnih zakonov širjenja signalov. Empirični pristop pa temelji na izvedbi praktičnih poskusov in izpeljavi formul na podlagi rezultatov poskusov. Pri bočnih sonarjih se v nekaterih primerih uporablja uravnavanje glede na vnaprej pripravljen fizikalni model odbojev signala pod različnimi koti in od različnih vrst morskega dna (teoretični pristop), vendar tak pristop pri mnogosnopnih sonarjih ne deluje zaradi bistveno višje frekvence (ICES 2007). Izkaže se, da je praktično nemogoče izdelati model za vse vrste dna in vse kote.

Uporabili smo empirični pristop. Opravili smo poskusne meritve in na testnih podatkih preverili več različnih metod, ki so se razlikovale predvsem glede na upoštevanje/neupoštevanje standardnega odklona in lokalno oziroma globalno povprečenje podatkov. Za najboljšo se je izkazala metoda, ki pri izračunu upošteva vse podatke (globalni pristop) in standardni odklon.

Uporabili smo formulo (ICES 2007):

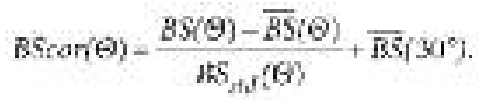

Normalizirano intenziteto odboja $B S \operatorname{cor}(\theta)$ za nek kot $\theta$ izračunamo kot razliko med izmerjeno intenziteto $B S(\theta)$ in povprečno intenziteto pri obravnavanem kotu vpada $\overline{B S}(\theta)$. Dobljeno razliko delimo s standardnim odklonom pri obravnavanem kotu $B S_{s t d}(\theta)$ in prištejemo povprečne intenzitete pri kotu $30^{\circ} \overline{B S}\left(30^{\circ}\right)$.

Tako obdelani podatki so neodvisni od nastavitev sistema, izločen je šum v podatkih in vpliv vpadnega kota na podatke. Podatki so tako pripravljeni za nadaljnjo obdelavo. 


\section{Izračun značilk za perpoznavanje morskih travnikov}

Značilke so neodvisne zvezne ali diskretne spremenljivke, ki opisujejo lastnosti podatkov. Cilj izračuna značilk je določanje tistih lastnosti akustičnih podatkov, ki bi lahko bile uporabne za razlikovanje med tipi morskega dna. Osredotočili smo se na značilke, ki bi nam pomagale v akustičnih podatkih zaznati morske travnike. Treba je izluščiti čim več značilk, uporabnih za kartiranje - želimo torej izluščiti informacije iz surovih podatkov (Pavešić 2012). Značilke so lahko osnovne meritve, kot je intenziteta odboja, ali pa bolj zapletene, kot so rezultati statističnih ali prostorskih analiz. Izračun ustreznih značilk je temelj za uspešno kartiranje morskega dna. Prednost sodobnih mnogosnopnih sonarjev je možnost hkratnega snemanja globin in podatkov o intenziteti odboja. V kombinaciji s sodobnimi GNSS lahko

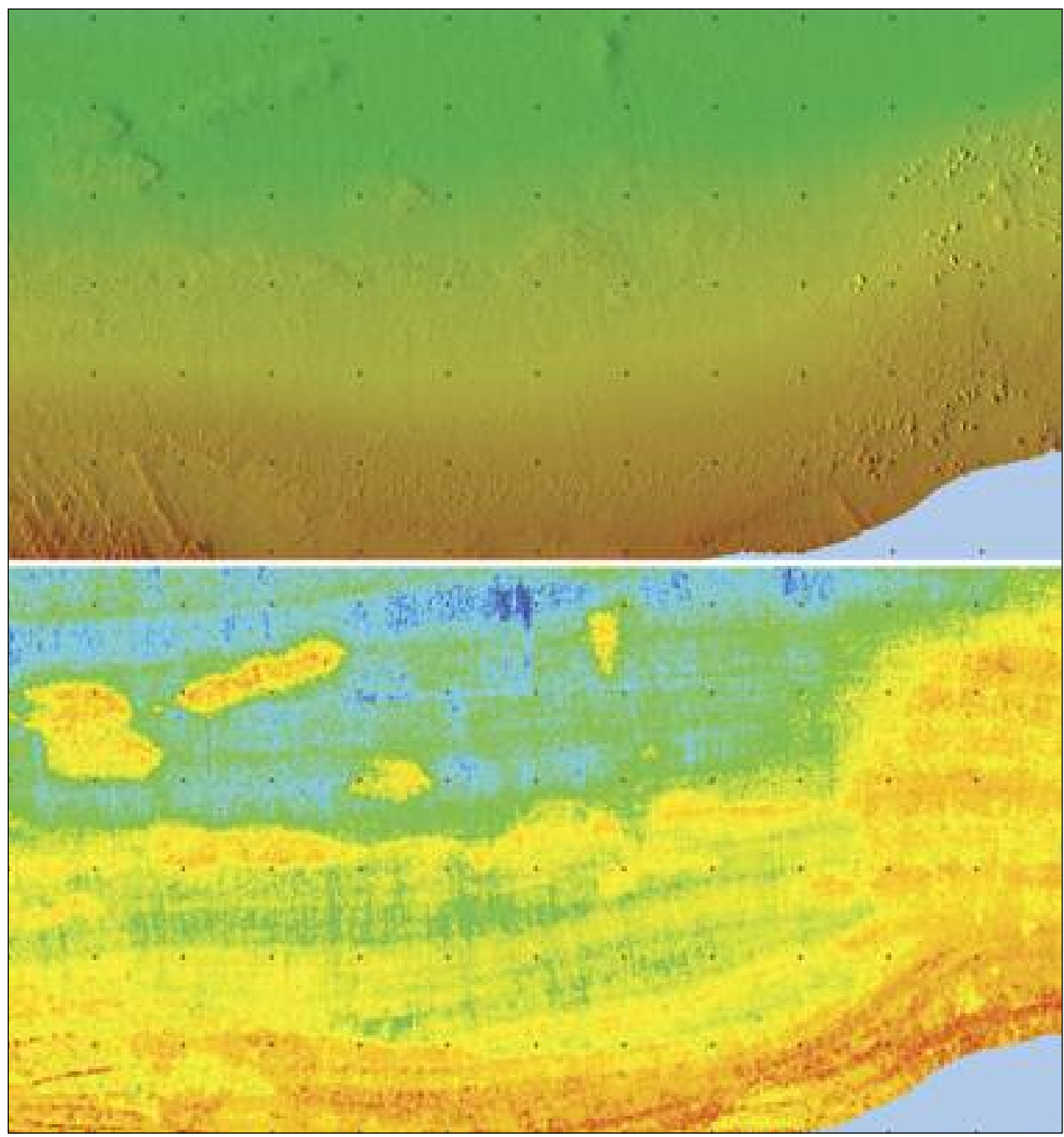

Slika 2: Primerjava slike batimetrij (zgoraj) in slike akustičnih odbojev (spodaj). 
podatke zelo natančno umestimo v prostor. Rezultat sta dva modela - batimetrični model (digitalni model globin) in model akustičnih odbojev. Iz posameznega odboja ne dobimo dovolj informacij, da bi sklepali na tip tal. Ker so podatki umeščeni v prostor, lahko izkoristimo prostorsko komponento. Prostorska komponenta nam omogoči, da podatke združimo v celice in na njih izvajamo prostorske analize. Podatke smo razdelili na celice velikosti $2 \times 2$ metra ter iz celic batimetričnega modela $\mathrm{v}$ nadaljevanju izračunali opisane karakteristike tal. Podobno smo iz slik akustičnih odbojev izračunali karakteristike slik akustičnih odbojev. Iz analiz batimetričnega modela je mogoče pridobiti veliko reliefnih podatkov o morskem dnu. Poleg tega globina vpliva na razporeditev habitatov, saj se z globino hitro zmanjšuje osvetljenost morskega dna in tudi izpostavljenost valovanju morja. Čeprav je analiza batimetrij učinkovita pri določanju reliefnih značilnosti morskega dna, pa sama po sebi ni uspešna pri določanju habitatnih tipov, če ni pomembnih razlik v topografiji habitatov. Morski travniki so prisotni na ravnem terenu, brez večjih naklonov ali izstopajočih oblik in jih le na podlagi batimetričnega modela zelo težko ločimo od muljastega ali peščenega dna. V nasprotju od analize batimetrij je analiza slik akustičnih odbojev manj intuitivna, saj analiziramo moč odbojev in ne globin. Primerjava batimetrij in globin je prikazana na sliki 2. Analize slik akustičnih odbojev za kartiranje morskega dna so se začele $\mathrm{z}$ uporabo bočnih sonarjev. Metode z uporabo matrik sopojavnosti sivin (GLCM - Grey-Level Co-occurrence Matrix) Fourier-jevih analiz in analizo oscilacij so se izkazale za uspešne (Attalah, Smith in Bates 2002). Cilj omenjenih metod je posnemanje principov človeškega vida, ki razlikuje med različnimi toni in teksturami.

Značilke, ki smo jih uporabili, lahko grobo razdelimo v dva razreda: karakteristike terena ter karakteristike slik akustičnih odbojev. Uporabili smo povprečno vrednost, standardni odklon, parcialne odvode, višje momente (asimetrijo in sploščenost) ter lastnosti matrike sopojavnosti sivin - kontrast, različnost, homogenost, energijo in korelacijo (Haralick, Shanmugam in Dinstein 1973). Vse naštete značilke smo izračunali iz obeh modelov, batimetričnega modela in modela akustičnih odbojev. Podatke smo izračunali za manjša območja kot tudi za večje dele morskega dna in tako pridobili širše znanje o razgibanosti reliefa ter akustičnih lastnostih morskega dna. Vsi ti podatki so pomembni pri določanju habitatnih tipov. Zelo pomembno je, da smo pred izpeljevanjem značilk iz obeh modelov izločili vplive gibanja plovila, vplive nastavitev opreme in izgube zaradi širjenja zvočnega signala v morski vodi. Izračunane karakteristike smo pretvorili v ustrezen format za obdelavo v orodju za podatkovno rudarjenje Orange (Demšar s sodelavci 2013).

\section{Kartiranje in preverjanje rezultatov}

Za klasifikacijo akustičnih podatkov smo uporabili fenomenološki pristop. Fenomenološki pristop predvideva obstoj korelacije med morfološkimi in fizičnimi lastnostmi morskega dna ter akustičnimi podatki. Pri fenomenološkem pristopu se po izpeljavi in izboru značilk uporabi nenadzorovano klasifikacijo. Nenadzorovana klasifikacija podatke razvrsti v skupine statistično podobnih enot. Podatke smo razdelili v akustične razrede brez direktnega sklepanja na dejanske fizične lastnosti dna. S pomočjo preverjanja (potapljači, zajem vzorcev, kamere) smo nato akustične razrede povezali z dejanskimi tipi tal. Uporabili smo postopek razvrščanja v skupine $\mathrm{z}$ metodo $\mathrm{k}$-tih voditeljev ( $k$-means clustering) (Hartigan in Wong 1979). Algoritem podatke razvrsti v skupine tako, da je razdalja med posameznimi podatki znotraj skupine čim manjša, razdalja med skupinami pa čim večja. Za delovanje algoritma so zelo pomembne: izbira razdalje, število želenih skupin in način začetne razporeditve po skupinah. Za razdaljo smo uporabili Evklidsko razdaljo, ki se najbolj pogosto uporablja pri takem razvrščanju. Algoritmu smo določili naključno začetno razporeditev. Za kartiranje morskih travnikov smo izbrali razdelitev podatkov v dve skupini, saj nas zanima le prisotnost oziroma odsotnost travnikov.

Za potrebe določanja dejanskega tipa tal in preverjanja rezultatov, smo podatke zbirali tudi vizualno. Uporabili smo metodo točkovnega vzorčenja s podvodnim fotoaparatom. Na podlagi zemljevida 


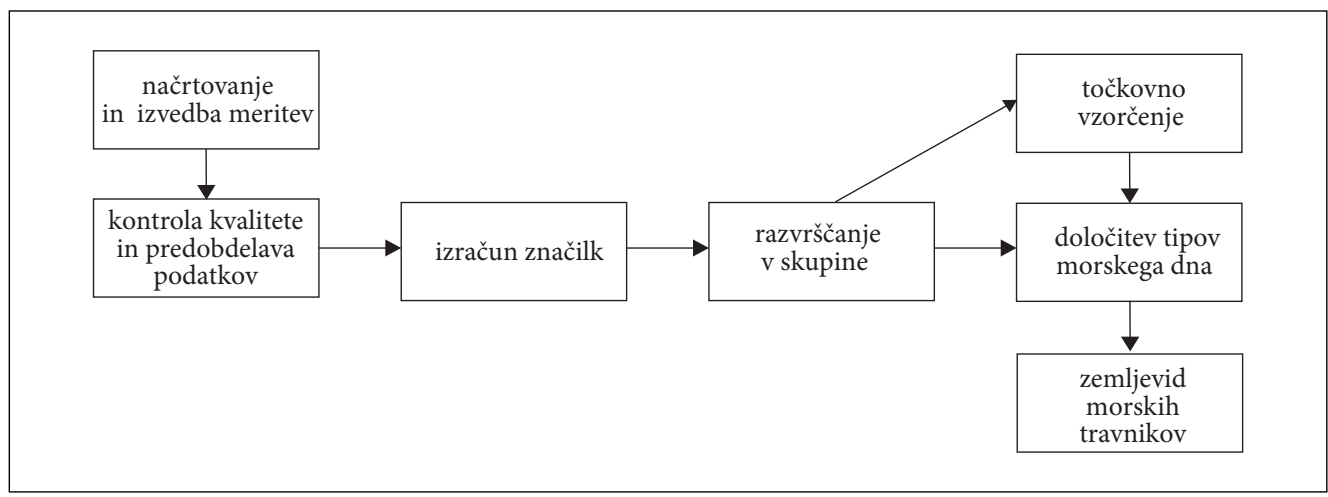

Slika 3: Diagram postopka kartiranja morskih travnikov. Prikazani so koraki od zajema podatkov do končnega zemljevida morskih travnikov.

morskih travnikov, ki smo ga pridobili s pomočjo razvrščanja podatkov v akustične razrede, smo določili točke vzorčenja. Točke smo vnesli v program za izvajanje meritev na plovilu Lyra, s katerim izvajamo hidrografske meritve. Na vsaki točki je potapljač fotografiral morsko dno. Na podlagi fotografij smo določili prisotnost morskih travnikov. Za oceno natančnosti dobljenega zemljevida morskih travnikov, smo rezultate primerjali tudi z letalskimi posnetki. Letalske posnetke smo posneli iz letala Cessna 172. Uporabili smo fotoaparat Nikon D700 z objektivom $50 \mathrm{~mm}$. Za določanje koordinat točke fotografiranja in natančne višine, smo uporabili GNSS Garmin GPS18. Fotografirali smo z relativne višine 1000 metrov. Za navigacijo in proženje fotoaparata smo uporabili programsko opremo, ki smo jo razvili sami v kombinaciji s programsko opremo za nadzor fotoaparata Nikon Camera Control. Fotografije smo zlepili s programsko opremo AutoPano Giga in jih georeferencirali v programskem orodju Qgis. Na letalskih posnetkih smo ročno označili morske travnike, pri tem smo si pomagali s fotografijami točkovnega vzorčenja. Dobljen zemljevid smo uporabili za primerjavo rezultatov avtomatske klasifikacije s pomočjo akustičnih podatkov mnogosnopnega sonarja.

\section{Rezultati}

Hidrografske meritve smo izvedli na območju med Izolo in Koprom. Območje je prikazano na sliki 5. Izbrano območje obsega 200 metrov širok in 900 metrov dolg obalni pas in pokriva 18 hektarjev morskega dna. Skupno je bilo zbranih 31 gigabajtov podatkov o preko 10.000 .000 točkah morskega dna. Podatke smo obdelali v razvitem modulu za avtomatsko predobdelavo podatkov in kartiranje morskega dna. Dobljen zemljevid morskega travnika je prikazana na sliki 5 z zeleno barvo. Izračunana površina morskega travnika je 32.050 kvadratnih metrov.

Glavni prednosti naše metode sta hitrost in zvezna pokrivnost obravnavanega področja. Hidrografske meritve obravnavanega območja smo izvedli v dveh urah, obdelava podatkov je trajala približno tri ure. $\mathrm{Na}$ ta način lahko travnik velikosti 32.050 kvadratnih metrov natančno kartiramo v enem delovnem dnevu, kar je bistveno manj časa kot bi ga porabili z vizualnimi ali mehanskimi metodami, omenjenimi v uvodu. Druga prednost je zvezna pokrivnost. Ločljivost naših podatkov na obravnavanem območju je v povprečju okoli 100 točk na kvadratni meter. Takšno ločljivost (izmed metod omenjenih v uvodu) dosega le bočni sonar, ki pa ima slabšo pozicijsko točnost in ne omogoča hkratnega snemanja globin in intenzitet odbojev (Anderson s sodelavci 2008).

Dobro načrtovanje meritev in lastna napredna programska oprema za izvajanje meritev nam omogočita pokritje celotnega obravnavanega območja brez »lukenj«. Tako ni potrebe po interpolaciji dobljenih 
rezultatov, kot je to potrebno pri kartiranju z vizualnimi metodami, mehanskimi metodami in enosnopnimi sonarji (Pandian s sodelavci 2009; Rooper 2008).

Za primerjavo dobljenih rezultatov smo izdelali zemljevid istega območja s fotointerpretacijo letalskih posnetkov. Za kakovostne letalske posnetke so pomembni trije dejavniki: dovolj svetlobe s pravim vpadnim kotom, mirno morje in relativno bistra voda. Območje smo določili na podlagi izkušenj z aerofotografijo, saj se je izkazalo, da je na izbranem območju ob ustreznih pogojih mogoče na fotografijah razločiti morske travnike. Aeroposnetki so prikazani na sliki 4.

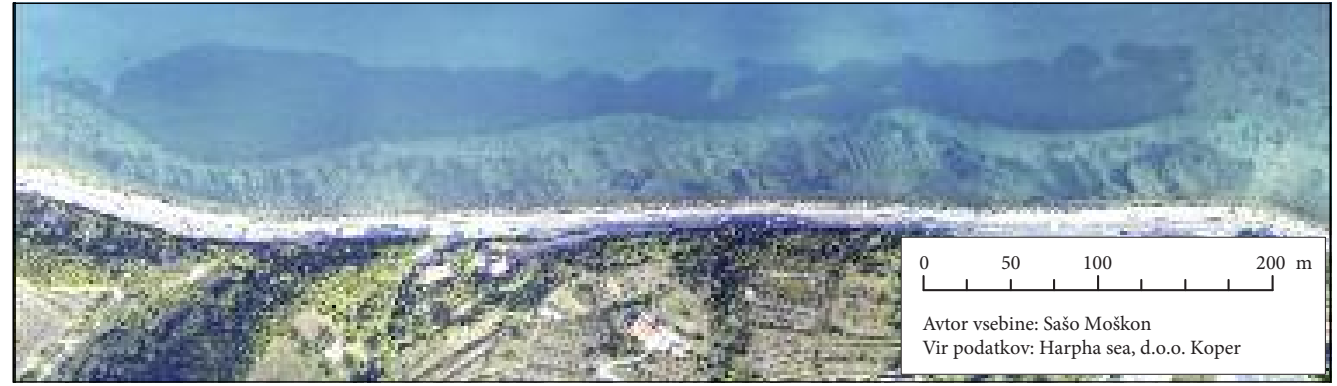

Slika 4: Aeroposnetki uporabljeni za fotointerpretacijo.

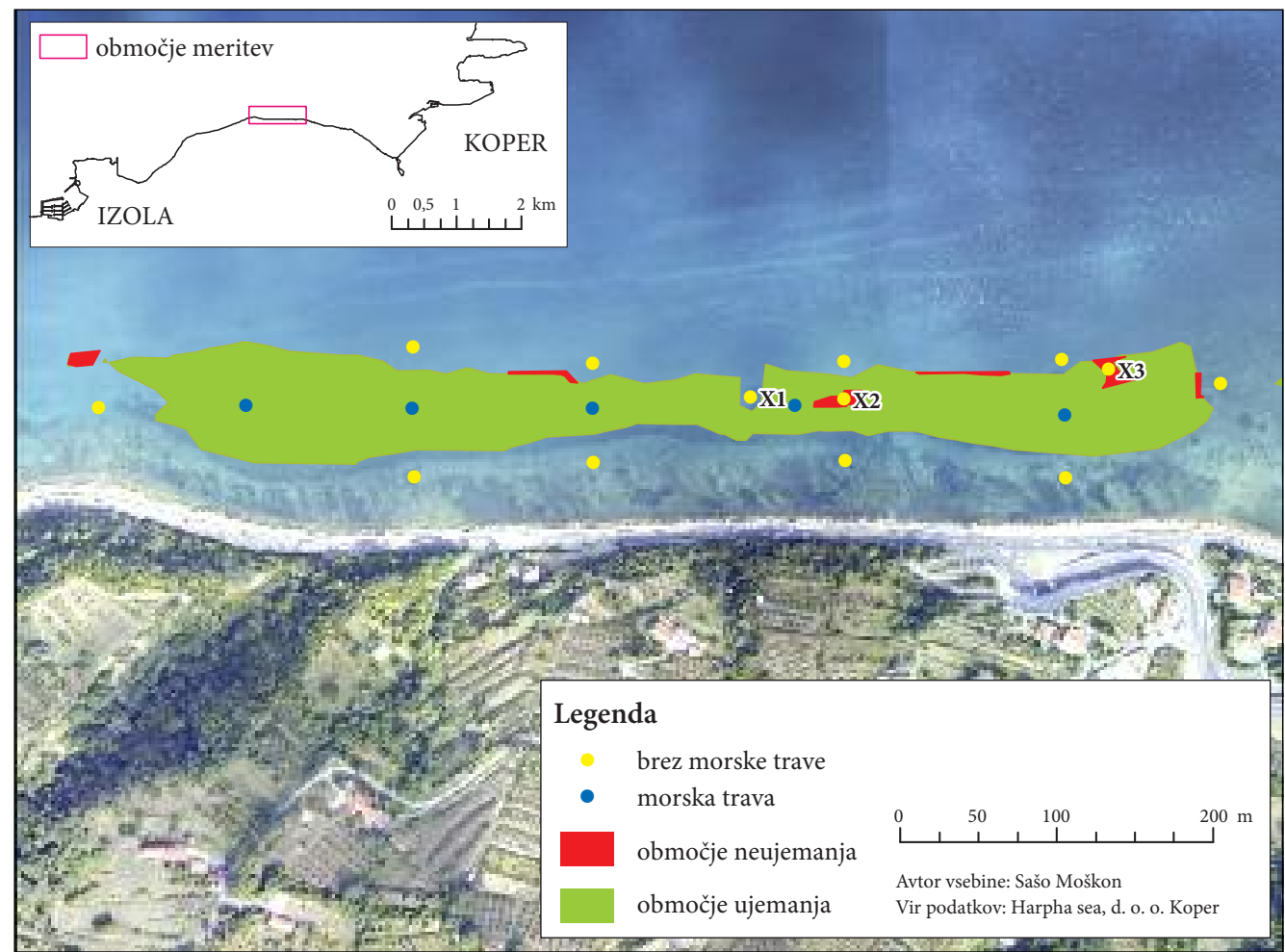

Slika 5: Primerjava poligonov ročno označenih travnikov in poligonov dobljenih $z$ akustičnim kartiranjem. $Z$ zeleno barvo je prikazano ujemanje obeh metod, $z$ rdečo pa območje neujemanja. $Z$ rumeno in modro so prikazane točke vzorčenja (podlaga: aeroposnetek območja). 
V orodju Qgis smo primerjali poligone izdelane s fotointerpretacijo aeroposnetkov in poligone dobljene z akustičnim kartiranjem ter dobili $96 \%$ prekrivanje. Večina neujemanja je na območjih prehoda med travniki in muljem, kjer je trava redkejša. Primerjava je prikazana na sliki 5 . Travnikov, ki smo jih fotointerpretirali iz letalskih fotografij seveda ne moremo upoštevati kot popolnoma zanesljivo metodo preverjanja, vendar pa velik delež ujemanja kaže na učinkovitost metode akustičnega kartiranja.

Za točkovno vzorčenje na terenu smo določili 18 točk. Točke vzorčenja so prikazane na sliki 5 . Z desetimi točkami smo zajeli okolico travnika, pet vzorčnih točk smo razporedili po dolžini v središču travnika, za preostale tri točke vzorčenja pa smo določili območja, kjer iz letalskega posnetka in akustičnih podatkov ni bilo jasno ali gre za morsko travo ali ne - torej območja, kjer sta se dobljena zemljevida razlikovala. Na sliki 5 so prikazani rezultati vzorčenja; modre oznake pomenijo travnik, rumene pa območja, kjer travnika ni.

Iz slike 5 je razvidno, da se dobljena zemljevida ujemata v 17 od 18 primerov. Vse tri metode se ujemajo v točkah okoli travnika in točkah razporejenih po središču travnika. Na omenjenih 15 točkah so vse tri metode podale enake rezultate, kar je bilo tudi pričakovano.

S točko X3 je označeno območje, ki ga je akustično kartiranje označilo kot travnik, iz letalskih posnetkov pa travnika tam nismo zaznali. S potopom na to območje smo ugotovili, da gre za dva metra širok pas mulja, ki na tistemu delu zareže v travnik. Točka X2 je območje, kjer smo z akustičnim kartiranjem prepoznali kamnito dno, sredi travnika. To iz letalskih posnetkov ni bilo razvidno. $S$ točkovnim vzorčenjem smo potrdili, da gre za kamnito morsko dno.

Tretje zanimivo območje je točka X1, kjer je morski travnik skoraj v celoti prekinjen. Iz letalskega posnetka je na tem delu razviden svetlejši pas, iz česar smo sklepali, da tam ni morske trave. Tudi akustično kartiranje nam je to območje označilo kot območje brez trave. S potopom smo ugotovili, da gre za kamnito morsko dno s treh strani obdano s travo. Na severu proti globini kamnito dno prehaja v mulj.

\section{Sklep}

Z raziskavo smo želeli pokazati, da so akustični podatki primerni za kartiranje morskih travnikov. Postopek je sicer zahteven, a hiter in uporaben. Na podlagi razvite metodologije smo uspešno izvedli meritve, obdelali akustične podatke ter na tej podlagi kartirali testni del morskega dna za določitev območja morskih travnikov. Ker za slovensko morje nimamo zemljevida tipov morskega dna, smo za preverjanje rezultatov uporabili letalske posnetke in točkovno vzorčenje s pomočjo potapljačev. Dobljen zemljevid morskega travnika se je v $96 \%$ prekrivala z območjem, fotointerpretiranim iz letalskih posnetkov. Točkovno vzorčenje je potrdilo ujemanje v 17 od 18 vzorčnih točk. S preverjanjem smo potrdili uspešnost naše metode in pokazali, da ima kartiranje s podatki mnogosnopnega sonarja velik potencial pri raziskavah morskega dna. Zavedamo se, da naša metoda še ni popolna in da je še veliko prostora za izboljšave. Opazili smo težave na prehodih med različnimi tipi morskega dna, kar je bilo pričakovano. Občasno se zgodi tudi, da z našo metodologijo ne razločimo ožjih pasov mulja obdanega z morskimi travniki, vendar pričakujemo, da bomo z izboljšavami predobdelave akustičnih podatkov in naprednejšimi metodami strojnega učenja to težavo rešili. Pomembna je ugotovitev, da metoda omogoča hitro kartiranje in zvezno pokrivnost večjih območij morskega dna. Z mnogosnopnim sonarjem lahko v enem dnevu izvedemo meritve in kartiramo območje veliko nekaj kvadratnih kilometrov. Prednost naše metode je tudi v robustnosti. Zajem podatkov $\mathrm{z}$ mnogosnopim sonarjem je neodvisen od prosojnosti vode in sončne svetlobe. Meritve je mogoče izvajati tudi v plitvih zalivih z zelo motno vodo. Prav tako nam natančni GNSS- in INS-sprejemniki omogočajo kakovostne meritve v vzvalovanem morju.

V prihodnosti bi radi razvili metodologijo za kartiranje več tipov morskega dna. Načrtujemo izboljšanje predobdelave podatkov in dodajanje novih značilk. Prav tako bomo preizkusili več različnih metod strojnega učenja, predvsem metod za nadzorovano učenje, s čimer želimo doseči natančnejše kartiranje tipov morskega dna. 
Zahvala: Raziskavo je delno financirala Evropska unija, in sicer iz Evropskega socialnega sklada, vokviru prve razvojne prioritete Operativnega programa razvoja človeških virov za obdobje 2007-2013: Spodbujanje podjetništva in prilagodljivosti, prednostne usmeritve 1.1.: Strokovnjaki in raziskovalci za konkurenčnost podjetij.

\section{Viri in literatura}

Anderson, J., Van Holiday, D., Kloser, R., Reid, D., Simrad, Y. 2008: Acoustic seabed classification: Current practice and future directions. ICES Journal of Marine Science 65-6. London. DOI: http://dx.doi.org/ 10.1093/icesjms/fsn061

Attalah, L., Smith, P., Bates, C. 2002: Wavelet analysis of bathymetric sidescan sonar data for the classification of seaflooor sediments in Hopvagen Bay - Norway. Marine Geophysical Researches 23-5. Dordrecht. DOI: http://dx.doi.org/10.1023/b:mari.0000018239.07561.76

Brown, C. 2007: Seafloor imagery, remote sensing and bathymetry: Acoustic ground discrimination system (AGDS). Marine Geology and Benthic Habitat Mapping 47.

Brown, C. 2009: Developments in the application of multibeam sonar bacscatter for seafloor habitat mapping. Applied Acoustics 70-10. DOI: http://dx.doi.org/10.1016/j.apacoust.2008.08.004

Brownrigg, D. R. K. 1984: The weighted median filter. Communications of the ACM 27-8. New York. DOI: http://dx.doi.org/10.1145/358198.358222

Demšar, J., Curk, T., Erjavec, A., Gorup, Č., Hočevar, T., Milutinović, M., Možina, M., Polajnar, M., Toplak, M., Starič, A., Štajdohar, M., Umek, L., Žagar, L., Žbontar, J., Žitnik, M., Zupan, B. 2013: Orange: Data mining toolbox in Python. Journal of Machine Learning Research 14. Cambridge.

Franklin, J. 2009: Mapping Species Distributions: Spatial Inference and Prediction. Cambridge. DOI: http://dx.doi.org/10.1017/cbo9780511810602

Fridl J., Kolega N., Žerjal A. 2008: Pomen digitalnega batimertičnega modela za trajnostni razvoj morja. Geodetski vestnik 52-4. Ljubljana.

Greenstreet, S. P. R., Holland, G. J., Guirey, E. J., Armstrong, E., Fraser, H. M., Gibb, I. M. 2010: Combining hydroacoustic seabed survey and grab sampling techniques to asses »local « sandeel population abundance. ICES Journal of Marine Science 67-5. London. DOI: http://dx.doi.org/10.1093/icesjms/fsp292

Guenther, G. C., Cunningham, A. G., LaRocque, P. E., Reid, D. J. 2000: Meeting the accuracy challenge in airborne lidar bathymetry. Proceedings of EARSeL-SIG-Workshop LIDAR. Dresden.

Haralick, R. M., Shanmugam K., Dinstein, I. 1973: Textural features for image classification. Systems, Man and Cybernetics, IEEE Transactions SMC-3, 6. DOI: http://dx.doi.org/10.1109/TSMC.1973.4309314

Hartigan, J. A., Wong, M. A. 1979: Algorithm AS 136: A K-means vlustering algorithm. Journal of the Royal Statistical Society 28-1. Oxford.

ICES 2007: Acoustic Seabed classification of marine physical and biological landscapes. ICES Cooperative Resarch Report 286. Kopenhagen.

IHO 2008: IHO Standards for Hydrographic Surveys. Monako.

Jogan, N., Kotarac, M., Lešnik, A. (ur.) 2004: Opredelitev območij evropsko pomembnih negozdnih habitatnih tipov s pomočjo razširjenosti značilnih rastlinskih vrst. Končno poročilo, Center

za kartografijo favne in flore. Miklavž na Dravskem polju.

Karničnik, I., Klanjšček, M., Radovan, D. 2006: Sodobno hidrografsko kartiranje in dokumentiranje slovenskega morja. Geodetski vestnik 50-1. Ljubljana.

Kolega, N., Poklar, M. 2012: Morphological analysis of the Slovenian coast with data from lidar and sonar ranging. Acta geographica Slovenica 52-1. Ljubljana. DOI: http://dx.doi.org/10.3986/AGS52105

Le Bas, T., Huvenne, V. 2009: Acquisition an processing of backscatter data for habitat mapping - comparison of multibeam and sidescan systems. Applied Acoustics 70-10. Kidlington. DOI: http://dx.doi.org/ 10.1016/j.apacoust.2008.07.010 
Lefsky, A. M., Cohen, W. B., Parker, G. G., Harding, D. J. 2002: Lidar remote sensing for ecosystem studies. BioScience 52-1. DOI: http://dx.doi.org/10.1641/0006-3568(2002)052[0019:LRSFES]2.0.CO;2

Mayer, L. A. 2006: Frontiers in seafloor mapping and visualization. Marine Geophysical Reasarches 27-1. Dordrecht. DOI: http://dx.doi.org/10.1007/s11001-005-0267-x

O'Neill, R., Ritters, K., Wickham, J., Jones, K. 1999: Landscape pattern metrics and regional assessment. Ecosystem Health 5-4. DOI: http://dx.doi.org/10.1046/j.1526-0992.1999.09942.x

Niemeyer, J., Soergel, U. 2013: Opportunities of airborne laser bathymetry for the monitoring of the sea bed on the Baltic Sea coast. International Archives of the Photogrammetry, Remote Sensing and Spatial Information Sciences XL-7/W2. Göttingen. DOI: http://dx.doi.org/10.5194/ isprsarchives-XL-7-W2-179-2013

Pandian, P. K., Ruscoe J. P., Shields, M., Side, J. C., Harris, R. E., Kerr, S. A., Bullen, C. R. 2009: Seabed habitat mapping techniques: an overview of the preformance of various systems. Mediterranean Marine Science 10-2. DOI: http://dx.doi.org/10.12681/mms.107

Pavešić, N. 2012: Razpoznavanje vzorcev: uvod v analizo in razumevanje vidnih in slušnih signalov. Ljubljana.

Poglajen S., Slavec, P. 2012: Podvodna kulturna dediščina in paleookolje iz hidrografskih in geofizikalnih podatkov slovenskega morja. Potopljena preteklost. Radovljica.

Rooper, C. N. 2008: Underwater video sleds: Versatile and cost effective tools for habitat mapping. Marine Habitat Mapping Tecnology for Alaska. DOI: http://dx.doi.org/10.4027/mhmta.2008.07

Van Overmeeren, R., Craeymeersch, J., van Dalfsen, J., Fey, F., van Heteren, S., Meesters, E. 2009: Acoustic habitat and shellfish mapping and monitoring in shallow coastal water - Sidescan sonar experiences in the Nederlands. Estuarine, Coastal and Sehlf Science 85-3. DOI: http://dx.doi.org/10.1016/ j.ecss.2009.07.016

Walker, B., Riegl, B., Dodge, R. 2008: Mapping coral reef habitats in southeast Florida using a combined technique approach. Journal of Coastal Research 24-5. DOI: http://dx.doi.org/10.2112/06-0809.1

\section{Summary: Mapping of marine meadows using multibeam sonar data} (edited by Martina Zajc)

The aim of our study was to show that acoustic data are suitable for mapping marine meadows. The process is demanding, but quick and useful. We developed a methodology, which includes all the necessary steps from data acquisition to mapping marine meadows.

Mapping of the seabed can be done visually, mechanically or acoustically. All visual methods (divers, video recording, photography) and mechanical methods (in-situ sampling) are slow and require a lot of effort, and consequently they are expensive and unsuitable for mapping large areas of the seabed. Development of aerial and satellite systems for remote sensing in the last few decades, increased availability of optical and laser remotely gathered data for studies of wider areas. This has contributed significantly to a better understanding of the spatial patterns of land. The applicability of optical methods at sea is limited to shallow coastal areas due to the limited penetration of light through the water. The more suitable are the bathymetric laser systems with a green laser that can reach two to three times Secchies depth, but they are still very dependent on water turbidity. In particular, usefulness of optical and laser methods is limited in the Slovenian sea and generally in a large part of the northern Adriatic due to the very turbid water. Multibeam sonars use audio signals, which are independent of the transparency of the water and allow us to collect high quality data even in areas where optical and laser methods fail. In addition multibeam echo sounders achieve significantly higher quality and resolution according to the criteria of the International Hydrographic Organization (IHO). Multibeam echo sounder systems meet the criteria of the IHO Special Order survey accuracy specifications, while bathymetric laser systems only meet criteria for IHO Order 1 survey accuracy specifications. Acoustic data can be 
measured by three different types of sonar systems - single-beam sonar, multibeam sonar and side-scan sonar. Multibeam and side-scan sonar systems collect data in a swath. They use up to 300 beams to simultaneously collect data about wide areas below the vessel, while single-beam sonar systems use just one beam at a time. Compared to side-scan sonar systems, multibeam sonar systems have the advantage of simultaneously collecting backscatter and bathymetry data. We used the Reson Seabat 8125 multibeam sonar for data acquisition. A multibeam sonar provides continuous coverage along with high speed of acquisition. We obtained two types of data - bathymetries and acoustic intensities. Both types of raw data from the multibeam sonar were processed in our data processing module. The data processing module included verification of data quality, elimination of the impact of system settings, normalization for incidence angle, derivation of features and mapping seabed meadows using data mining. Verification of data quality was based on a median filter for image processing. After the verification of data quality, elimination of the impact of system settings and normalization for incidence angle was performed by means of empirically derived formulas. The interaction between the acoustic signal, sea-water and seabed under different incidence angles is too complex for theoretical treatment, which is why an empirical approach using planned experimental measurements and comparison of results was taken. Further, we derived features from pre-processed data. We divided both types of data - bathymetries and intensities of acoustic reflections - into patches sized $2 \times 2$ meters. For every patch specific simple features like average value, standard deviation and partial derivatives were computed and more complex texture features like higher moments and grey-level co-occurrence matrix properties were derived. All features were then used in a k-means clustering machine-learning algorithm to produce seabed meadow maps.

Based on the developed methodology, measurements carried out, acoustic data processed and areas of seabed meadows were determined. An area of the Slovenian sea between the cities of Izola and Koper was chosen, due to favourable conditions for verifying results. The test area of the size of 180,000 square meters was measured. As we do not have maps of seabed types for the Slovenian sea, we had to verify the results using aerial photography and spot sampling using divers. The resulting map of marine meadows overlaps in $96 \%$ with the areas marked manually on the basis of aerial photography. Spot sampling confirmed the map of marine meadows in 17 of 18 sampling spots. We mapped a total of 35,050 square meters of marine meadows over 180,000 square meters of the treated area. We confirmed the effectiveness of our method and demonstrated that mapping marine meadows using multibeam sonar data has great potential in seabed research.

We are aware that our method is not yet complete and that there is still room for research and improvements. We noticed problems at the transitions between the different types of seabed, which was expected. Occasionally it also happens that our methodology does not distinguish narrow bands of silt surrounded by marine meadows, but we expect to improve this by improved data pre-processing and using advanced methods for data mining. It is important to note that the method allows rapid mapping and continuous coverage of large areas. With a multibeam sonar, it is possible to carry out measurements and map areas of several square kilometres in just one day. The advantage of our method is also in its robustness. Collecting data with a multibeam sonar is independent of the transparency of water and quantity of sunlight. Measurements can be performed in shallow waters with very turbid water. Advanced GNSS receivers and accurate INS sensors enable high-quality measurements in the undulating sea. 